\title{
The press and military conflict in early modern Scotland
}

by

\author{
Alastair J. Mann
}

A soldier fights for three separate but sometimes associated reasons: for duty, for payment and for cause. Nathianiel Hawthorne once said of valour, however, that 'he is only brave who has affections to fight for'. Those soldiers who are prepared most readily to risk their lives are those driven by political and religious passions. From the advent of printing to the present day the printed word has provided governments and generals with a means to galvanise support and to delineate both the emotional and rational reasons for participation in conflict. Like steel and gunpowder, the press was generally available to all military propagandists in early modern Europe, and so a press war was characteristic of outbreaks of civil war and inter-national war, and thus it was for those conflicts involving the Scottish soldier.

Did Scotland's early modern soldiers carry print into battle? Paul Huhnerfeld, the biographer of the German philosopher and Nazi Martin Heidegger, provides the curious revelation that German soldiers who died at the Russian front in the Second World War were to be found with copies of Heidegger's popular philosophical works, with all their nihilism and anti-Semitism, in their knapsacks. ${ }^{1}$ The evidence for such proximity between print and combat is inconclusive for early modern Scotland, at least in any large scale. Officers and military chaplains certainly obtained religious pamphlets during the covenanting period from 1638 to 1651. The major Scottish regiments of the Low Countries, raised in 1586, 1603 and 1628 in order to fight the Spanish, had a number of chaplains, the longest serving being Andrew Hunter who ministered to the soldiers from 1590 to 1630 . Hunter was in 1604 in debt to the great Edinburgh bookseller and printer Andro Hart (c.1565-1621), a committed presbyterian who had even been a 'puritan' spy for Queen Elizabeth. It is most likely that Hunter was providing his regiment with liturgical printed matter and in particular printings of the Confession of Faith. Like William Wallace, the elder and factor of Veere in Zeeland (Scotland's staple port), who took it upon himself in 1618 and 1619 to buy Scottish Psalters for his church and Scottish merchant community, Hunter had clear print obligations. As for English language bibles, though expensive to the ordinary soldier, the Low Countries was awash with English language editions from the late $1620 \mathrm{~s}^{2}$

Military chaplains were, like blacksmiths, specialists whose weapons were not swords or muskets. Their importance to military campaigns was quite specific, even though most specialists surely carried weapons for use in emergencies. Thus it was for booksellers and more especially printers who, of course, were skilled in the art and science of printing. Some book traders did enlist as ordinary soldiers, as did the Edinburgh bookseller Andrew Symers who joined the Jacobite army in 1745. Part-time soldiering was also taken up: the printer George Mosman (f.1685-1707) was a captain in the Edinburgh militia in the 1690s. ${ }^{3}$ Others had a background of military service before entering the book trade or moved in and out of soldiering and trade. 
Edward Raban (c. 1585-1658), Aberdeen's first printer (1622-50) and associate of the Pilgrim Press of Leiden that in 1617-19 produced the 'seditious' presbyterian tracts of David Calderwood (1575-1651), is an interesting example of a printer who was also a professional soldier. Born in England of German stock, Raban's early adulthood was as a soldier fighting for Maurice of Nassau and the Dutch Republic against Catholic Spain. This war raged from 1572 to 1609 at which point an unsteady ten-years' truce was signed. Raban joined the Dutch and their Anglo-Scottish confederates in 1600 and was immediately pitched into the battle of Nieuwpoort (30 June), where the Dutch were defeated but managed to withdraw. Two decades later Raban, with the distorted view of the proud soldier, recalled Nieuwpoort a victory for the republic: it was not. In fact Raban's military career was lengthy. Gordon E. Duff's vivid portrait of Raban as soldier of fortune concludes, using internal evidence from passages of autobiography in Raban's printing, that he was in continuous activity as a soldier until 1610 before wandering Europe, especially Germany, and settling at Leiden in 1612. Raban's own tale in his Resolutions against Drunkenness (1622), that his master in Leiden 'burnt [his] house, himself, and his only daughter' has led to as yet futile efforts to search for a printer who suffered this catastrophe and was therefore Raban's master. This would perhaps, it could be argued, account for his activity in the years 1612-17 before the advent of the Pilgrim Press. However, testimonials in the judicial archives at Leiden indicate that Raban was known as a printer as early as October 1607. Furthermore, in 1613, a testimonial for Raban written by the Leiden alderman and university printer Jacob Jacobson, describing Raban as 'wel gehert en guede wetensches' (well tempered and good in knowledge), suggests Raban had learnt his trade not in Leiden but from the Amsterdam printer Francoise Lammelinson. ${ }^{4}$ Raban's own statement that he was a soldier for ten years, coupled with these details, shows his military career was not continuous as assumed by Duff and his travels around the Low Countries were indeed extensive. Military campaigns were punctuated by periods of relative peace and opportunities for trade, commerce and travel. Simultaneous press and sword activity was simply impractical for individual printers and, in the eyes of the managers of warfare, an inefficient use of propaganda resources.

There were, nonetheless, a variety of incidences of the Scottish press in the theatre of war in the early modern period. Some of these arose from skirmishes rather than full-scale war. Regional conflicts, or periods of intermittent unrest, simultaneously gave rise to and fed on press activity, especially emanating from the two main sources of Scottish print dissent Edinburgh and Holland. During the controversy surrounding the introduction of the Five Articles of Perth (1618-25), James VI's plans to introduce Anglican levels of ritual in Scottish church services including kneeling, the Scottish Privy Council and church Court of High Commission had difficulties and yet some success in suppressing printed dissent. ${ }^{5}$ Anonymous authorship and printing made detection problematical of course.

The arrival in the summer of 1619 of David Calderwood's anonymous Perth Assembly, and anti-ritual and staunchly presbyterian tract, infuriated the government and episcopacy and resulted in the houses and booths of the Edinburgh book traders Andro Hart, Richard Lawson (f.1603-22) and James Cathkin (f.1601-31) being searched and ransacked as the 
authorities sought to establish the printer, distributors and author of the offending work. Cathkin was interrogated in London by the king himself. ${ }^{6}$ In fact all three were already known to the authorities as presbyterians and supporters of Andrew Melville (15451622), the leader of presbyterian radicalism in the reign of James VI and I. Hart and Cathkin had even been arrested in Edinburgh's presbyterian riots of December $1596 .{ }^{7}$ But Calderwood's work of polemic had been printed at Leiden not Edinburgh. Indeed, since the 1590s the authorities had become increasingly concerned at the activities of AngloScottish presses at Middelburg, Amsterdam and Leiden, which proliferated Brownist writings, that is those advocating the views of the Middelburg cleric Robert Brown on independent congregations, and also pamphlets supporting Scotland's exiled and persecuted presbyterian clergy. ${ }^{8}$

The royal ambassadors to The Hague, Dudley Carlton (f.1616-28) and Henry Vane (f.1628-33) and William Boswell (f.1633-50), did what they could to halt the Dutch presses at source. Carlton became obsessed with Perth Assembly and Calderwood, persuading the Dutch authorities into the futile interrogation of Richard Schilders the Middelburg printer and eventually to close the Leiden press of William Brewster and Thomas Brewer who had actually printed the book. Brewster fled across the Atlantic with the Pilgrim Fathers, so providing his Leiden press with the bibliographical sobriquet 'The Pilgrim Press', and Brewer took sanctuary in the University of Leiden. It is, however, symbolic of the continuation of the exiled puritan press that some of the 'Pilgrim Press' type came into the hands of the separatist presses of Giles Thorp (f.1604-22), his successors (f.1623-35) and John Canne (f.1637-44), all at Amsterdam. Even Edward Raban inherited some of the type and went on to print a Latin edition of Perth Assembly in 1620. Nevertheless, the ambassadorial effort continued to even greater effect in the reign of Charles I, and in 1637 and 1638 William Boswell persuaded respectively the magistrates of Leiden and Amsterdam to fine and confiscate the stock of William Christiaensz van der Boxe and John Canne for printing subversive texts including George Gillespie's Dispute Against the English Popish Ceremonies Obtruded upon the Church of Scotland (1637). ${ }^{9}$ Never had British authorities been so successful in silencing an opposition press overseas.

The Restoration brought both the return of monarchy and the return of the Dutch press as a factor in political and religious controversy, yet the context was different form the 1620s: peaceful protest replaced by armed conflict. The years from 1665 to 1685, and culminating in the 'Killing Times' (1681-85), represented a brutal period of persecution of covenanters, and in particular those in the south and west most opposed to episcopalianism and lay patronage of the church. But although Charles II's commanders, Sir James Dalyell at Rullion Green (1666), the terminus of the Pentland Rising, and James, Duke of Monmouth and John Graham of Claverhouse at Bothwell Brig (1679), inflicted military defeat on the covenanter rebellions, silencing the covenanter press was much more difficult to engineer. In the field, there is no evidence that the covenanter forces had their own printing press, although they certainly had material printed by anonymous sympathisers, probably the presbyterian presses of James Glen (f.1656-90) and George Mosman in Edinburgh and Robert Sanders, the elder (f.1661-94) in Glasgow. Covenanter statements like the Sanquar Declaration (1680) and Lanark Declaration 
(1681) had to be duplicated for distribution. These printed manifestos were carried widely by the soldiers of King Jesus both at armed field conventicles and to the various skirmishes between government forces and the godly. The Sanquar Declaration was printed only a few weeks before the action at Airds Moss in Ayrshire ( 22 July, 1680) where a small detachment of the extreme covenanter faction, the Cameronians, along with their leader Richard Cameron, was defeated by General Tam Dalyell's dragoons. In February 1682 William Harvey, a Lanark weaver and Cameronian, was sentenced to death for his part in the covenanter rebellion of 1679 but also for publishing the Lanark Declaration. The government realised, more than ever before, that printed sedition sat easily with armed insurrection, and indeed more books were banned in the 1680s than in any other decade in Scotland's early modern period, though that did not halt the covert printing of the likes of James Renwick's Apologetical Declaration and Admonitory Vindication of the True Presbyterians of the Church of Scotland (1684) and his Testimony against the Toleration (1688) published in the year of his execution. ${ }^{10}$

Much banning of books or not, the stream of printed covenanter and presbyterian polemic was relentless from 1660 to 1688. In particular, the Dutch press, which entered the controversies in the reigns of James VI and I and Charles I and had become so adept at supplying English language bibles to Anglo-Scottish readers from the 1620s, was again able to print more lengthy treatises and material too dangerous for domestic production. This Dutch bounty, and especially now out of Rotterdam, provided covenanters with intellectual and spiritual support for their stop-go civil war against the Restoration episcopal church settlement.

After the symbolic and posthumous publishing in Rotterdam of the letters of the late and great presbyterian divine Samuel Rutherford (c.1600-61) - these appeared in Joshua redivivus (1664) and engendered much spiritual excitement in military and clerical presbyterians in Scotland and abroad - a stream of tracts by exiled presbyterians poured from the presses of Rotterdam. John Brown of Wamphrey, exiled in 1663, had his Apologeticall Relation of the Particular Sufferings of the Faithful Ministers and Professors of the Church of Scotland since 1660 (1665) printed at Rotterdam as did Sir James Stewart of Goodtrees and James Stirling's Naphtali, or the Wrestlings of the Church of Scotland (1667). They were promptly banned and committed to the flame by the Scottish Privy Council. But the pace increased across the North Sea, as the Dutch divine Jacobus Koelman set himself in business in Rotterdam as a tireless editor and translator of Scottish presbyterianism, preparing editions in Dutch and Latin and encouraging further editions in English. For example, Brown's Christ the Way, the Truth, and the Life (Rotterdam, 1677) was printed for the Edinburgh bookseller John Cairns a year after its publication in Dutch. Other Dutch print centres joined the fray, Flushing printing in 1673 the complete letters of Rutherford in Dutch, while the banished minister Robert MacWard had his infamous presbyterian tract The Poor Man's Cup of Cold Water, Ministered to the Saints and Sufferers for Christ in Scotland printed in Amsterdam in 1678. In fact, by the late 1670s the period of radical publishing out of Rotterdam was drawing to a close. In the aftermath of the murder of James Sharp, Archbishop of St. Andrews in May 1679, the press war of information and misinformation now took place on the domestic stage. Presbyterianism now had the 
ability to print covertly within Scotland through the presses of the likes of George Mosman and James Glen. Once a Dutchman came to the throne of England and Scotland the presses of Holland ceased to have major role as a catalyst for dissent and intermittent military rebellions, but nonetheless, when all looked lost in the aftermath of Rullion Green and Bothwell Brig the Dutch press played its part in sustaining a sense of hope in the minds and hearts of the soldiers of God. ${ }^{11}$

Press warfare in the decades between the Revolution of 1688/9 and the Union of the Parliament in 1707 was, even in the absence of dissenting voices from Holland, an increasingly international affair within the British Isles. The dispersed and confused nature of the immediate revolution saw printed matter supportive of King James VII appear in Ireland, England and Scotland along side the propaganda of the new regime. However, the speed of the revolution in Scotland and the effective policing of the press by the Williamite and presbyterian convention and committee of estates gave the Jacobite leaders little opportunity to use sympathetic printers to encourage support. The leading Jacobite George Gordon, Duke of Gordon (1643-1716) may have held Edinburgh Castle for King James in 1688-9 yet he was effectively a close prisoner with no typographic opportunities. Also, John Graham, Viscount Dundee, the Jacobite commander, had but a few months between his withdrawal from the convention of estates in March 1689 and his greatest victory and fateful death at the battle of Killiecrankie the following July. Dundee's successor commanders Colonel Alexander Cannon and General Thomas Buchan also had little opportunity to use the press before their eventual defeat by government forces under Sir Thomas Livingstone at Cromdale in Speyside on 1 May 1690. Even Major-General Hugh Mackay, William and Mary's commander-in-chief in Scotland, was no print pugilist. His memoirs and correspondence show him to be more concerned with supplies and the condition of his forces, and their simple exhaustion was one of the reasons for his reverse at Killiecrankie. ${ }^{12}$

Jacobite defeat at Cromdale, and as importantly defeat in Ireland followed by the pacifying Treaty of Limerick of October 1691, did not halt what existed of Scotland's Jacobite/Williamite press war. Indeed, there was a new context of party politics, put simplistically episcopalian Tories versus presbyterian Whigs, where opposition and orderly dissent was legitimised. Also, the growing resentment at English economic imperialism, especially interference in the doomed attempt to set up a Scottish trading company at Darien in Panama, and the targeted censoring of the most offensive texts only, as the news press expanded and censorship punishments moderated, increased both Jacobite press activity and the consequent government response. ${ }^{13}$ Both Jacobites and episcopalian opportunists conflated economic grievances with the restoration of King James and succession questions, as did Walter Herries, the author of various pro-Darien tracts most of which were banned by the government in 1700. Meanwhile, the thorny issue of church politics obsessed many, and presbyterians in the Scottish government, such as James Johnston (1655-1737), secretary of state, continued to be exercised by episcopalian tracts from England, such as Robert Calder's Scottish Presbyterian Eloquence (London, 1693), which mocked presbyterianism and so required a rejoinder. ${ }^{14}$ 
The general election of 1702, which produced a hung parliament where a third of MPs were Jacobite, increased both the legitimate and extremist debate in print. Opposition to the union of the parliaments was added to the cocktail of dissent created by Jacobitism and the Darien fiasco. The government in Westminster, realising it was now too provocative to print anti-Jacobite material in Edinburgh, used the London press to counter Jacobitism and opposition to the union. ${ }^{15}$ Meanwhile, the expanding print culture of Edinburgh was a relatively safe-haven for the distributors of printed dissent, just as it was for the network of presbyterian booksellers in the reigns of James VI and Charles I. A small band of ministers expelled from the church at the revolution turned to the book trade to earn a living and to spread their episcopalian ideas. This network, known in Edinburgh as the 'Killicranky stationers', included the bookseller Henry Knox (d.1716), former minister of Bowden and Dunscore, the bookseller, printer and poet Andrew Symson (d.1712), former minister at Kirkinner and Douglas and the bookseller David Freebairn (d.1739), former minister of Gask, Auchterarder and Dunning who, after the Toleration Act of 1712, eventually became bishop of Edinburgh in $1722{ }^{16}$ This book distribution network appeared to auger well for Jacobitism before and after the union of 1707, but the political opposition after 1702 was hopelessly divided in Scotland, as James Francis Edward Stewart discovered with the abortive Franco-Jacobite invasion of 1709.

Print encouragement of sporadic conflict was but one aspect of the relation between the military and printing. Like King Charles I in the bishops war of 1639, when he took a press to Newcastle, and Oliver Cromwell in 1650, when he entered Scotland with his own press, printers and their materials were sometimes part of the baggage trains of Scottish armies. The press being close to or near the actual theatre of war added immediacy to proclamations, declarations of intent and explanations of short term motive.

The earliest incidence of this in Scottish history was during the Marian civil war (156773) when Robert Lekpreuik (f.1561-82) printed for the king's men (those favouring the regime on behalf of the infant James VI) and Thomas Bassandyne (f.1564-77) printed for the queen's men (the supporters of Mary, Queen of Scots). As the queen's party controlled Edinburgh Castle and the capital from April 1571, the governor of the castle, the distinguished soldier and veteran of French campaigns Sir William Kirkcaldy of Grange (c.1520-73) having switched to the Queen, Bassandyne was generally based in Edinburgh for much of the conflict. Some of his work must have been carried out within the castle walls. Meanwhile Lekpreuik's press was by necessity more mobile. He printed in Edinburgh and probably Leith before Kirkcaldy's conversion in 1571 when he fled with his press to Stirling. However, the Marian attack on Stirling the following September, which was led by George Gordon, 5th earl of Huntly (d.1576) and resulted in the death of the regent Matthew Stewart, 4th earl of Lennox (1516-71), forced Lekpreuik to relocate to St. Andrews. ${ }^{17}$ Printing could certainly be a hazardous business.

Bassandyne's output during the war has been lost, the fate no doubt of being on the losing side, while much of Lekpreuik's work has survived or is known to us, including his printing of George Buchanan's Chamaeleon (1570/1), a satire on the machiavellian role played in Scottish politics by William Maitland of Lethington (c.1525-73) who, like Kirkcaldy, treacherously switched to the Queen. Kirkcaldy and Maitland attempted to 
arrest Lekpreuik in the act of printing this work but the printer just evaded capture before his flight to Stirling. Indeed, before and after this episode Lekpreuik produced numerous printings of vicious anti-Marian propaganda as found in other prose works of Buchanan and in the verse of Robert Sempill. Ironically, although Bassandyne was arrested and charged with conspiring with those 'rebels' who held the castle for the Queen, he was pardoned by the Regent Morton in 1573 and went on to be licensed by church and state to print Scotland's first domestic bible. Meanwhile, the victorious Lekpreuik was in prison in early 1574 for the unlicensed printing of a tract critical of the government's church policy, John Davidson's Ane Dialog or mutuall talking betuix a clerk and ane Courteour concerning four Parische Kirks till ane Minister (1574). ${ }^{18}$ In times of peace or times of war fate moved in mysterious ways for Scotland's printers.

Lekpreuik and Bassandyne were Scots but Scottish military commanders also had to use foreign printers even in the Scottish theatre. In 1649 James Graham, 1st Marquis of Montrose (1612-50), regrouping in exile after his brilliant campaign for Charles I, used the presses of Copenhagen and Gothenburg to print his new Declaration against the Scottish estates. This was just before his return to Scotland and final action and defeat at the battle of Carbisdale in April 1650. However, in 1685 Archibald Campbell, 9th earl of Argyll (1629-85), brought a foreign press and printer with him when he carried out the doomed Argyll Rising, timed to coincide with the Duke of Monmouth's equally doomed effort to invade England. Argyll landed at Kintyre in April 1685 and in his baggage train was the Dutch printer Geills Willamsone. Willamsone had been trained by the Amsterdam printer and bookseller Jacob Vandervelde. The circumstances by which he came to join Argyll are unknown, and the printer's own account of his naivety to events is not entirely convincing. Willamsone certainly produced Argyll's Declaration and apology for the protestant people, apparently at Campbeltown. The Declaration also appeared in a Dutch translation unlikely to have been printed in Scotland in spite of 'Schotlandt' being the stated place of printing. Either way, after Argyll's inept campaign petered out, he being even unable to take Inveraray which was held firmly for the government by John Murray, 1st Marquis of Atholl, Willamsone was soon captured along with his press and materials. In June his master Argyll met the executioner, and that same month the printer was sentenced to six months imprisonment in the tolbooth of Edinburgh for printing the Declaration. This was a typical maximum sentence, and was matched by that given to the German Catholic printer Peter Breusch in 1689. In 1688 Breusch (or Bruce) succeeded to the anomalous position of 'household printer'(as opposed to king's printer) to James VII, replacing the Catholic convert James Watson, the elder (f.1685-7) as, in effect, printer in residence at Holyrood Abbey. In December 1688, as revolution fervour gripped Edinburgh, Breusch's press and materials were destroyed when Alexander Swinton, Lord Mersington led the indiscriminate attack on Holyrood Abbey by a rabble supported by the town guard which smashed property and arrested 'papists' with equal measure. ${ }^{19}$ Breusch then served the familiar term in the burgh tolbooth.

We have seen that Jacobite sympathisers among book traders were fairly common in Edinburgh from 1690 and beyond the union of 1707. In fact episcopalian as opposed to presbyterian book traders had been present in Edinburgh throughout the seventeenth 
century. From the episcopalian bookseller Gilbert Dick (f.1600-19), who took legal action to protect his liturgical copyrights in the closing years of reign of James VI, to James Watson, the younger (f.1695-1722) and son of the Catholic printer of the same name, who was the wealthy news printer who first produced the Edinburgh Gazette (1699) and then suffered imprisonment in 1700 for publishing material that too heatedly mixed the Jacobite, Darien and episcopalian cocktail of protest, we find book traders fighting the presbyterian tide of Scottish history. ${ }^{20}$ So in September 1715 when the chronic turncoat John Erskine, 11th earl of Mar (1675-1732) finally raised the standard for James Francis Edward Stewart, it is not so surprising that Robert Freebairn (f.1701 47), son of David the episcopalian minister and bookseller, a substantial book trader and part-owner of the royal printing patent, was ready to depart from Edinburgh to meet with the Jacobite forces at their Perth headquarters. He clearly accepted his father's Jacobite views. Mar took possession of Perth on 28 September and Freebairn had joined him no later than 14 October. $^{21}$

According to John, Master of Sinclair, one of the Jacobites gathered at Perth and who looked back with jaundiced eyes, it was John Campbell, earl of Breadalbane who suggested that if they must 'idle at Perth' then they should 'get a printing-press and ...print Gazets'. ${ }^{22}$ Freebairn had left Edinburgh in too great a hurry to bring his own press and materials, and so there was a debate over where press and types could be obtained. In the first days of the rebellion, a not entirely unsympathetic Aberdeen had given way to the Jacobites and some of the town council were replaced by supporters of Mar's rebellion. Therefore, on 20 October, when the magistrates of Aberdeen met to discuss Mar's request, it was agreed to despatch to Perth the press and type of the town printer James Nicoll (f.1710-49), willingly or reluctantly is not clear. At least efforts were made to pack the materials appropriately and to indemnify Nicoll for any damage. It seems likely, however, that if Nicoll was a Jacobite he would have accompanied his own press to Perth. Nicoll, in any case, was not in the same personal danger as Edward Raban, Aberdeen's first printer, some decades before. In 1644 Raban found himself obliged to print the Declaration of James Marquis of Montrose after the cavalier had occupied Aberdeen. ${ }^{23}$ This printing may not have taken place at the point of a sword but the implicit threat was clear enough, Montrose having just sacked the city..

Freebairn needed no such persuasion in 1715. While Mar dallied too long when he had numerical strength over government forces, and then delivered the ignominious draw that was the battle of Sheriffmuir (13 November) when he outnumbered the government troops of John Campbell, 2nd Duke of Argyll (1678-1743) by roughly three to one, Freebairn busied himself with printing in Perth from the end of October. Couper suggests that Freebairn's later Continental career as a courier and diplomat moving between exiled Jacobites in France and Italy mitigates against his personal labour at the press, and it is possible his servant Robert Drummond, who took possession of Nicoll's press in Aberdeen, was a trained printer. But, supervisor or journeyman, Freebairn's press issued a stream of army orders, proclamations and Jacobite propaganda sheets, such as Scotland's Lament, Confabulation and Prayer (1715), to encourage Highlanders and others to stick to the cause regardless of the setback at Sheriffmuir. Nonetheless, by January Mar, Freebairn and his press had retreated to Aberdeen, the first two then into 
exile and the latter returning to the workshop of James Nicoll, printer to the town until 1736. In spite of considerable setbacks Freebairn himself persisted with his book trade career, acting as a book merchant supplying the literati of Scotland and selling stock to clear his debts. Eventually he returned to Edinburgh in c1722 to assert successfully his right to part of the gift of king's printer. ${ }^{24}$

The rebellion of 1715 was the last, best chance for Jacobite success. The generation later that passed judgement on the rebellion of 1745 was more accustomed to the benefits of the union. What had been in 1715 a mass movement including the Lowlands was more a Highland and noble affair in 1745. Print propaganda would need to be reinvented, notwithstanding the Jacobite tendencies of journals such as the Caledonian Mercury. Nevertheless, from the raising of the standard at Glenfinnan in August 1745, the swift passage and victories of the charismatic Prince Charles Edward Stewart and his astute general Lord George Murray ensured, within six weeks, the rout of government forces under Sir John Cope at the battle of Prestonpans (21 September) and the overrunning of all Scotland. Success seemed a real possibility. The 'Young Pretender' reached Derby undefeated in December although, finding very little support from the Scottish Lowlands or England, Murray was forced to deliver his brilliant tactical withdrawal which resulted in Jacobite victory at Falkirk in January. Unfortunately for the rebels this was made irrelevant by the delayed demise of Jacobitism at Culloden in April 1746. Much of this failed campaign was very swiftly joined, especially the period between August 1745 and January 1746, and so there was little time for Robert Freebairn's press to make a difference.

In fact the Jacobite army appeared very slow to take full advantage of a specific army field press. A notice in the Caledonian Mercury of 10 January 1746 provides the evidence for a belated effort to organise a press and printers:

'[The Jacobites] carried off from Glasgow a printing press, types and other materials for that business, together with some servants to work in that way. When they carried off these materials they did it in this manner, that is, from one printer they took a press, from another some types, and from a third chases, furniture, etc. This happened when the insurgents were on their final retreat northward. ${ }^{25}$

By 1745 Glasgow had several presses and we cannot be certain from which press shops these materials were taken or the identity of those 'servants' employed in producing Prince Charles's Declaration and other proclamations. The Jacobites stayed in Edinburgh for over a month before marching into England and during this time must have used unidentified Edinburgh presses for army orders and the like. In fact James Grant, printer and newswriter and a partner of the famous Ruddimans in Edinburgh, joined Lord Ogilvie's regiment as a lieutenant before being commissioned captain and serving throughout the campaign. It is not clear how much soldiering he actually experienced. After Culloden he crossed to Breda and the home of his son-in-law. Back in Scotland Grant stood accused, in his absence, of having 'printed several treasonable papers' for the rebels. Also, according to his own statement on his eventual arrest re-entering at Harwich in January 1748, Grant carried out few military duties and instead was employed by John Murray of Broughton, the king's secretary who later turned king's evidence, in the printing of Jacobite proclamations and papers. Some of this work was surely carried out 
in Edinburgh before the assembling of the Glasgow materials. It is possible though that Grant used the Glasgow type and press to produce the paper the Bannockburn Journal in which an account appeared of the Jacobite victory at Falkirk. In any case, Grant was released after only a few weeks in prison. ${ }^{26}$

In addition James Ged, son of William Ged (1690-1749) the Edinburgh goldsmith and inventor of the printing stereoplate (this removed the costly business of resetting for each reprint), found himself imprisoned in 1746 as 'printer to the rebels'. Ged seems to have been captured at Carlisle and transferred to Edinburgh but, although condemned to death, was pardoned through his father's influence. Afterwards, James worked briefly as a printer with Bettenham's press in London in the Strand before emigrating to Jamaica where his younger brother William had started printing as a reputable printer. Unfortunately, James died soon after his arrival in the West Indies. ${ }^{27}$

There is one other belated print victim of the rigorous government clampdown that followed the 1745 rebellion. One of the Jacobite prisoners Thomas Ruddiman, the younger (f.1740-47), had inherited his famous father and namesake's interest in the proprietorship of the Caledonian Mercury, as well as the notable Jacobitism of the family. The son was re-arrested in November 1746 and imprisoned yet again in the Edinburgh tolbooth. Ruddiman junior had printed in the Mercury a caustic paragraph too critical of the government. After six weeks in prison he was released but then died of an illness contracted in the prison. ${ }^{28}$ Although not a single printer in early modern Scotland suffered the punishment of execution, prison was hardly a very pleasant experience.

While the exertions of the military press in the Marian civil war, Argyll Rising and Jacobite rebellions are noteworthy, nothing in the early modern period matched the activity of the covenanter press from 1638 to $1643 .{ }^{29}$ The mainstays of covenanter domestic printing in these years were the Edinburgh brothers James Bryson (f.1630-42) and Robert Bryson (f.1637-45). James had been a bookseller since at least 1630 and acquired in 1639 the press of Andro Hart's widow Janet Kene, while Robert, probably the younger of the two, had traded as a bookseller since 1637 and began printing, both in his own right and with his brother, in 1640. In fact the printer to make the first notable contribution to the revolution was George Anderson, Glasgow's first printer. Anderson is famous for having printed The Protestation of the Generall Assemblie of the Church of Scotland which arose from the determination of the Glasgow Assembly of November 1638 to abolish episcopacy. The reason for all this anxiety, the hated but superbly printed Prayer Book of 1637, had been produced by the Englishman and Scottish royal printer Robert Young (f.1625-43). Young fled from to his London press after the Prayer Book riots began, yet his business partner and fellow printer and Englishman Evan Tyler (f.1639-82) remained in Edinburgh. Indeed, one of the most puzzling decisions of the covenanting regime was not to oppose Charles I's appointment of Young and Tyler as joint king's printers in June 1641. The Brysons made a formal though vain protest to the estates that they, as loyal presbyterians, had been overlooked in favour of the 'strangeris' Young and Tyler. The decision of the estates, and ratification by parliament in 1644, reflects an unwillingness to challenge the king unnecessarily over an issue of commercial 
property, but also the fact that Tyler was a good and obedient printer, as would be shown by his behaviour up to $1651 .^{30}$

As Charles I struggled to comprehend the motives of those who signed the National Covenant war seemed inevitable. The outbreak of the 'bishops' wars' of May-June 1639 and August-September 1640 created the need for print propaganda to explain the intentions of the new regime in Edinburgh. The regime turned both to the domestic presses of the Brysons and to the sympathetic printers of Holland yet not, as far as is known, to a press near the field of battle. In spite of this, the years 1639 and 1640 witnessed a veritable blitzkrieg of print propaganda out of Holland and Edinburgh. The target audience was not only domestic but also English and European. Above all the English parliament had to be reassured that the Scots were not hostile to their interests. In 1639 the Remonstrance of the Nobility, Barons and Burgesses was printed by James Bryson in Edinburgh and, using falsified imprints, John Canne of Amsterdam produced further Dutch and English editions. Information from the States of the Kingdom of Scotland (1640) was printed again by James Bryson but also in the same year by the Cloppenburg press at Amsterdam. That year The Intentions of the Army of the Kingdom of Scotland was printed by Cloppenburg, Christiaensz van der Boxe at Leiden and by Robert Bryson in Edinburgh. The Lawfulness of our Expedition into England (1640) even appeared in a 'Mar-Prelate' London edition, as well as from Christiaensz, Cloppenburg and Robert Bryson. Christiaensz and Cloppenburg also printed A Remonstrance Concerning the Present Troubles, although no Bryson edition of this covenanting statement has survived. Meanwhile, John Canne in Amsterdam took it upon himself to produce Dutch editions of almost all the covenanting propaganda for the years 1639 and $1640 .{ }^{31}$

The planning and organisation of this international press effort was largely down to Archibald Johnston of Wariston (1611-63), clerk of the general assembly, advocate for the kirk and a leading figure in the covenanting regime. He used his various clerical contacts in Holland to facilitate the many printings, although the role of the Brysons was also crucial. The covenanters paid James and Robert Bryson over $£ 1000$ Scots for printing carried out in 1640. Robert received the largest sum 'for the pryce of ane number of Bookes and declaratiounis sent in to England be publict orders before the armie went ther in anno 1640'. Interestingly, he also received a fee for his 'expenss, service and hazard in goeing in throghe England with the saids bookes' ${ }^{32}$ Robert Bryson may not have been a combatant, but he certainly risked his life to bring the propaganda of the covenant to the brethren of England.

Domestic printing to sustain the military effort and secure the government continued in 1641 and 1642, with the likes of articles and ordinances of war and instructions to officers requiring to be printed. Generally the revolutionary regime was more stable and there was less need for international support, even though dissenting voices had already seen the marquis of Montrose experience a few months imprisonment. However, after 1642 there were changes to the political context for official printing and the printers available to carry out the work. In 1643 negotiations with the English parliament over the Solemn League and Covenant brought the army of the covenant into the English civil 
war, but also created the impression among the Scots government, falsely as it turned out, that the English now understood the fervour of the National Covenant, and that regular and effective channels of communications had been successfully put in place. Print propaganda was now less important than print administration. Also, by 1645 both Brysons were dead and Anderson in Glasgow would soon follow, and the Edinburgh authorities had to turn to Tyler, now financially tied to the Stationers' Company in London, with occasional help from Raban in Aberdeen. The tensions and dispute over the Engagement crisis of 1647-8, where moderates sought to come to terms with the imprisoned Charles I, produced a flurry of competing declarations and proclamations from kirk and estates. Remarkably, Tyler printed both sides of the argument as had Raban over the National Covenant in 1638, although neither gained much credit for their evenhandedness. There was time in 1648, however, for a last hurrah for print in support of military effort. The Engagers agreed to print a journal to convey news of Scotland and the army now entering England and on 16 August 1648 Ane Information of the Publict Proceedings of the Kingdom of Scotland, and their Armies was published having been printed anonymously by Tyler. Copies were immediately despatched to England but too late, the following day the Engager army, led by the James, 1st Duke of Hamilton (160649), was roundly defeated by Cromwell at the battle of Preston. ${ }^{33}$

We have no evidence that the armies of Alexander Leslie, 1st earl of Leven (c.15801661), in 1639-41 and 1643-47, the Duke of Hamilton in 1648 or David Leslie (d.1682) in 1650 and 1651 carried printing presses. The accounts from Leven's army of 1643-47 appear to make no mention of a press or printed matter. ${ }^{34}$ In part this may be explained by a shortage of printers and presses in Scotland at the time, as well as by the undoubted centralising tendencies of the committee of estates during the 1640s. In any case, communications with a professional army had been improved to such a point that matter could be printed in Edinburgh and sent quickly by despatch to the army in the field. Meanwhile, the possibilities for domestic royalist printing, as opposed to English or continental, was firstly hampered by the unanimity of the National Covenant and then by the effectiveness of the covenanting censor, and only briefly appeared in Scotland after Montrose took Aberdeen in 1644. Good fortune as much as careful planning was required to facilitate printing in or near the field of conflict. As for the print threat from afar, when in 1649 the exiled Montrose produced his new royalist Declaration from the presses of Scandinavia, the committee of estates moved quickly in early 1650 to arrange a counterdeclaration from Tyler's press. ${ }^{35}$

Printers and army commanders or leading politicians were in effect the manufacturers and publishers of army press material. However, the question of motivation for printers is peculiarly difficult to assess. Robert Lekpreuik has been judged an 'ultra-Protestant' with his support of the king's men in the Marian civil war and his extensive output of Protestant liturgy, but Davidson's Ane Dialog or Mutuall talking betuix a Clerk and ane Courteour, which Lekpreuik printed in 1574 and then suffered imprisonment, was a critique of poor provision of the church not Protestant polemic. Lekpreuik also printed for court Catholics in the reign of Mary, Queen of Scots. Thomas Bassandyne has been accused of printing a 'pro-Catholic' work The Fall of the Roman Kirk, although this was an Erastian tract, and so an episcoplian and not a Catholic work. Equally we cannot be 
certain if Raban willingly co-operated with Montrose in 1644 or Nicoll with the earl of Mar in 1715. In many instances commercial considerations came to the fore. Anomalies such as the presbyterian John Reid, the elder, printing the Remonstrance and protestation against deposing James II (1689) can only be accounted for by the fact that he was paid to print the job. ${ }^{36}$ Nevertheless, printers could be as committed to the cause as any Scottish soldier, and the likes of Robert Lekpreuik, Robert Bryson, Robert Freebairn and James Grant were close enough to their respective fields of battle.

For those who commanded soldiers and presses, in all parties and in conflicts great and small, there was at least unanimity on the importance of print to the optimum prosecution of war. Nothing reflects this more clearly than the attitude of a range of authorities to the publication of Timothy Pont's (c.1565-c.1614) cartography of Scotland from the surveys and maps he completed in the 1580s and 1590s. Although not, of course, a question of blatant propaganda, the importance of mapping Scotland for military and administrative purposes ensured the project was supported and encouraged by James VI, by Charles I, by Archibald Campbell, $1^{\text {st }}$ marquis of Argyll, by Robert Lilburne, commander of the Commonwealth forces in Scotland under Cromwell, who recommended to Cromwell the usefulness of the maps for military purposes, and lastly by Cromwell himself who granted the Dutch printer Johan Blaeu (1596-1673) a copyright and licence to print his Atlas Novus (1654), volume five, based on a large number of Pont's detailed maps of Scotland. ${ }^{37}$ This example illustrates the shared interest in the development of print media but at the same time conveys that sense of opportunism which characterised the interaction between the press and the military in early modern Scotland. Winning the press war was seen as a vital aspect of effective campaigning. The press was not so much equal to the sword as a vital complimentary device. Whether as printed Confessions of Faith in the hands of the ordinary soldier, as printed commands between generals and officers or as printed communications and declarations between political leaders and the population at large, the power of the press became fundamental to all varieties of military conflict in early modern Scotland.

\footnotetext{
${ }^{1}$ Peter Gay, Weimer Culture: The Outsider as Insider (Harmondsworth, 1974), 85.

2 J. Ferguson, (ed.), Papers Illustrating the History of the Scots Brigade in the service of the United Netherlands, 1572-1772 (Edinburgh, SHS, 1899), i, 57; D. Laing, (ed.), The Bannatyne Miscellany, (Edinburgh, 1827-55), ii, 240; Gemeentearchief Veere: Records of the Church at Veere, Account Book I (1616-35), f. 14r and 19; Alastair. J. Mann, The Scottish Book Trade: Print Commerce and Print Control in Early Modern Scotland ( East Linton, 2000), 91-3. For Hart, ibid., passim, forthcoming entry in New Dictionary of National Bibliography by A.J. Mann and for a rather dated but useful summary see W. Cowan, 'Andro Hart and His Press: with a handlist of his books' in Papers of the Edinburgh Bibliographical Society, i (1896), no. 12, 1-14.

${ }^{3}$ A List of Persons concerned in The Rebellion, 1745-6 (Edinburgh, SHR, 1890), 256. Possibly related to the bookseller Alexander Symer also of Edinburgh. For Mosman see NLS. Scottish Book Trade Database (SBTI) and NAS. RD2/94, no. 1772, f.870-2.

${ }^{4}$ E. Gordon Duff 'The Early Career of Edward Raban, Afterwards First Printer at Aberdeen', The Library, 4th ser, ii, (1921-2), 239-56; Gemeentearchief Leiden, Rechterlijk Archief, Getuigenisboeken 1581-1810 (inv. No. 79), I, 217 (25 October, 1607) and L. 224 (15 February, 1613) and for Raban's arrival in Aberdeen Mann, Scottish Book Trade, 9-10. Raban's optimistic account of the battle of Nieuwpoort is also in his Resolutions against Drunkenness. See Duff 'Edward Raban', 240-1 and Geoffrey Parker, The Dutch Revolt (Harmondsworth, 1985), 234-5.
} 
${ }^{5}$ Mann, Scottish Book Trade, 59-62. G. McMahon, 'The Scottish Courts of High Commission, 1610-38' in Records of the Scottish Church History Society, xv, pt. iii, (1965) 200-3 and Mann, 'The Book Trade and Public Policy in Early Modern Scotland, c.1500-c.1720 (PhD, Stirling, 1997), 101-2.

${ }^{6}$ David Calderwood, The History of the Kirk of Scotland ( 8 vols.) (Edinburgh, 1842-9), vii, 348-9, 357-64, 380-2, 433-41, 477-8, 596-611 and 618-19; John Spottiswoode, History of the Church of Scotland (1655), ed. M. Russell, (3 vols.) (Edinburgh, 1847-51), iii, 268-9. For Cathkin interrogation see 'A Relation of James Cathkin: His Imprisonment and Examination About Printing the Nullitie of Perth Assembly, by Himself' in Bannatyne Miscellany, i, pt.2, 199-215.

${ }^{7}$ Calderwood, History v, 510-12 and 520-1.

${ }^{8}$ For early government measures see $A P S$, iv, 187 and $R P C$, i, 6, 18 (1599) and $R P C$, i, 10, 339-40 (1615). Mann, Scottish Book Trade, 167.

${ }^{9}$ Ralph Winwood, Memorials of the Affairs of State (London, 1725), ii, 195; Public Record Office, State Papers Domestic 84/69, 177; 84/153, 183-90; 84/154, 150-3; 16/387, no. 79; Dudley Carlton, The Letters from and to Sir Dudley Carlton, Kent, during his Embassy in Holland from January 1615/16 to December 1620 (London, 1780), 335, 351, 379; Algemeen Rijksarchief, The Hague [ARF], Resolutions of the States General, no. 3180, 17; Gemeentarchief Amsterdam [GAA], Rechterliijk Archief (Arch. no. 5061), Justitieboek, no. 578, f.267v; K.L. Sprunger, Dutch Puritanism: A History of English and Scottish Churches of the Netherlands in the Sixteenth and Seventeenth Centuries (Leiden, 1982), 237-47; Sprunger, Trumpets from the Tower: English Puritan Printing in the Netherlands (Leiden, 1994), 37-41, 121-2 and for a summary Mann, Scottish Book Trade, 88-91.

${ }^{10}$ Mann, Scottish Book Trade, 179-183; For Harvey RPC, iii, 7, 342 and for Renwick trail see NAS, [Justiciary Court Records, Books of Adjournal] JC2.17 (8 February, 1688).

${ }^{11}$ RPC, iii, 2, 138-9 and ibid., 375-6; W. Steven, The History of the Scottish Church at Rotterdam (Edinburgh/Rotterdam, 1832), 29-30 and 72-112; A.L. Drummond, The Kirk and the Continent (Edinburgh, 1956), 99-109; NAS. RH4. 17/2-8. doc.9; Robert Wodrow, The History of the Sufferings of the Church of Scotland (1721/2) (4 vols.) (Glasgow, 1828), ii, 7; James Kirkton, The Secret and True History of the Church of Scotland from the Restoration to the year 1678 (ed. R. Stewart) (1993), 79 and Mann, Scottish Book Trade, 84-86, 165 and 172-3.

${ }^{12}$ P.W.J. Riley, King William and the Scottish Politicians (Edinburgh, 1979), 1-20; W. Feguson, Scotland: 1689 to the Present (Edinburgh, 1978), 8-11; Mann, Scottish Book Trade, 174; Hugh Mackay, Memoirs of the War Carried on in Scotland and Ireland 1689-91 (Edinburgh, 1833), passim.

${ }^{13}$ Mann, Scottish Book Trade, 174-6.

${ }^{14}$ For Privy Council actions against tracts pro-Darien see NAS. PC.1.51, 576 and 583, and PC.1.52,14. For Herries see APS, x, 211 and NAS. PC.1.52, 163-4. NAS. (State Papers) SP.3.1 Letter James Johnston to Ormistoun (Justice Clerk), (23 February, 1693); Johnston to Sir James Stewart (Lord Advocate) (28 March, 1693) and Johnston to earl of Portland (11 May, 1693).

${ }^{15}$ K.M. Brown, Kingdom or Province?: Scotland and the Regal Union, 1603-1715 (London, 1993), 181-2; Margaret Steele, 'Anti-Jacobite pamphleteering, 1701-1720' in SHR, 1x, 2, no.170 (1981), 140-55 and Mann, Scottish Book Trade, 149-50.

${ }^{16}$ For presbyterian book trade network connected by marriage see A. J. Mann, 'Embroidery to Enterprise: the Role of Women in the Book Trade of Early Modern Scotland' in Ewan and Meikle (eds.) Women in Scotland, c.1100 - c.1750 (East Linton, 1999), 141-3. For 'Killiecrankie Stationers' see W.J. Couper 'The Pretender's Printer: Robert Freebairn', SHR, xv, (1917), 106; W.J. Couper 'Andrew Symson: printer and poet', SHR, xiii 47-67 (1916) and H. R. Plomer, A Dictionary of the Printers and Booksellers who were at work in England, Scotland and Ireland from 1668 to 1725 (Oxford, 1968), 182 and 283-4.

${ }^{17}$ R. Dickson and J.P. Edmond, Annals of Scottish Printing (1890, reprinted Amsterdam 1975), 198-272 (for Lekpreuik and works printed) and 273-311 (for Bassandyne and works printed); Mann, Scottish Book Trade, 37 and 150-52; Bannatyne Miscellany, ii, 218 for Bassandyne's will and testament.

${ }^{18}$ Annals of Scottish Printing, 203-4 and 250; Registrum Secreti Sigilli Regum Scotorum: Register of the Privy Seal of Scotland, vi, 274 and 350; RPC, i, 2, 727; Calderwood, History of the Kirk, iii, 301-2; Mann, Scottish Book Trade, 141 and 184.

${ }^{19}$ Steve Murdoch, 'The Search for Northern Allies: Stuart and Cromwellian Propagandists and Protagonists in Scandinavia, 1649-60' in Propaganda: Political Rhetoric and Identity 1300-2000 (Gloucestershire, 1999), 83; Mann, Scottish Book Trade, 152 and 184; RPC, iii, 11, 306 and 427; Dr. J. Lee, Memorial for the Bible Societies in Scotland (Edinburgh, 1824), 146; RPC, iii, 12, 460-1; John Lauder of Fountainhall, 
The Decisions of the Lords of Council and Session from June 6th 1678 to July 30th 1712 (2 vols.), (Edinburgh, 1759-61), i, 424; NAS. PS. 3.4, 248 and RPC, iii, 13, xx. Note Breusch was also and engineer and papermaker.

${ }^{20}$ NAS. PC. 1.26, 70; RPC, i, 11, 626; Mann, Scottish Book Trade, 45, 100, 107 and 129-130; NAS. PC.1.52, 114-17; W.J. Couper, 'James Watson, King's Printer' SHR, vii, (1910), 249-51; NAS. High Court of Justiciary, minute books JC6/14; NAS. PC.1,52,109; Mann, Scottish Book Trade, 142, and 176. ${ }^{21}$ W.J. Couper, 'The Pretender's Printer' SHR, xv, (1917), 106-23; Couper, 'The King's Press at Perth, 1715-16' SHR, xvii, (1919); Mann, Scottish Book Trade, 123.

22 John, Master of Sinclair, Memoirs of the Insurrection in Scotland (Edinburgh, Abbotsford, 1858), 186.

${ }^{23} \mathrm{~J}$. Stuart, (ed.), Extracts from the Records of the Burgh of Aberdeen (1625-1747) (Aberdeen, 1871-2), ii, 355; Mann, Scottish Book Trade, 144 and 152.

${ }^{24}$ Couper, 'Pretender's Printer', 113 and Mann, Scottish Book Trade, 121,123 and 153; NAS. CC.1.6.31 and J. P. Edmond, The Aberdeen Printers, 1620 to 1736 (4 vols.), (Aberdeen, 1884), iv, lvii-lxiv.

${ }^{25}$ Caledonian Mercury (10 January, 1746) quoted in G. Chalmers, The Life of Thomas Ruddiman (Edinburgh, 1794), 208.

${ }^{26}$ B. G. Seaton and J. G. Arnot (eds.), The Prisoners of the '45 (Edinburgh, SHS, 1928), i, 135-6; Robert Forbes, The Lyon in Mourning (3 vols.) ed. H. Paton, (Edinburgh, SHS, 1895-96), ii, 197 and A List of Persons concerned in the Rebellion, 1745-6 (Edinburgh, SHS, 1890), 248.

${ }^{27}$ Persons concerned in the Rebellion, 1745-6, 248 and 379. NLS. Scottish Book Trade Database (SBTI).

${ }^{28}$ Prisoners of the '45, i, 136; Chalmers, Life of Ruddiman, 207. NLS. Scottish Book Trade Database (SBTI) and Plomer, Dictionary of the Printers and Booksellers, 1668 to 1725, 258-9.

${ }^{29}$ For a general overview of covenanter printing see D. Stevenson, 'A Revolutionary Regime and the Press: the Scottish Covnenters and their Printers 1638-1651', The Library, sixth series, ii (1985), 315-37 and Mann, Scottish Book Trade, 83-6.

${ }^{30}$ Registerum Magni Sigille Regum Scotorum: Register of the Great Seal of Scotland [RMS], ix, no. 967; APS, vi, i, 257-8; Stevenson, 'Scottish Covenanters and their Printers', 325-6 and Mann, Scottish Book Trade, 40. For Bryson complaint see 'Information anent his Majestie's Printers in Scotland' in J. Maidment (ed.), Spottiswoode Miscellany (Edinburgh, 1844), i, 299-301 and for the testaments of both Brysons see Bannatyne Miscellany, ii, 259 and 263.

${ }^{31}$ Sprunger, Trumpets from the Tower, 197-217; H. G. Aldis, A List of Books Printed in Scotland before 1700 (Edinburgh, 1970), range no. 936-81; Mann, Scottish Book Trade, 83-4.

${ }^{32}$ NAS. PA.14/1, Register of the Committee for Common Burdens, 1641-5, f.156r and f.157r and Stevenson, 'Scottish Covenanters and their Printers', 325.

${ }^{33}$ Brown, Kingdom or Province?, 122-32; Mann, Scottish Book Trade, 44, 117-8; Plomer, Dictionary of Booksellers and Printers, 1641-1667, 184-5; Stevenson, 'Scotland's First Newspaper, 1648' The Bibliotheck, 10 (1981), 123-26.

${ }^{34}$ For example see C.S. Terry (ed.), Papers Relating to the Army of the Solemn League and Covenant, 1643-1647 (2 vols.) (Edinburgh, SHS, 1917).

${ }^{35}$ NAS. Register of the Committee of Estates, 1649-50, f.46v.

${ }^{36}$ P. B. Watry, 'Sixteenth Century Printing Types and Ornaments of Scotland with an Introductory Survey of the Scottish Book Trade' (PhD, Oxford, 1992), 28, 31, 36 and 40; M. Lynch (ed.), 'Mary Stewart: Queen in Three Kingdoms', Innes Review (1987), xxxviii, 27n; RPC, iii, 16, 228 and 248 and Mann, Scottish Book Trade, 150-3.

${ }^{37}$ For a summary of the long and complex publication of the Pont/Blaeu atlas see A. J. Mann, "The Atlas of the 'Flemish priest': Government, law and the publishing of the first atlas of Scotland" in Publishing History, 50, (2002). 